\title{
Explaining Protectionism Support: The Role of Economic Factors
}

\author{
Natalia Melgar, ${ }^{1}$ Juliette Milgram-Baleix, ${ }^{2}$ and Máximo Rossi ${ }^{1}$ \\ ${ }^{1}$ Department of Economics, University of the Republic, Constituyente 1502, 11200 Montevideo, Uruguay \\ ${ }^{2}$ Department of Economic Theory and History, University of Granada, Campus Cartuja, 18071 Granada, Spain
}

Correspondence should be addressed to Natalia Melgar; nmelgar@decon.edu.uy

Received 8 November 2012; Accepted 26 November 2012

Academic Editors: T. M. Dall and D. Mitra

Copyright (C) 2013 Natalia Melgar et al. This is an open access article distributed under the Creative Commons Attribution License, which permits unrestricted use, distribution, and reproduction in any medium, provided the original work is properly cited.

\begin{abstract}
We find that individuals' opinions concerning protectionist policies match with how their revenue could be affected in the medium or long term by trade liberalisation in line with predictions of the comparative advantage models. An adverse macroeconomic context (large increase in the unemployment rate or inflation rate) increases protectionist attitudes, thus reflecting that people do not trust that free trade will lead to lower prices or create jobs despite trade theory optimism. People share a mercantilist view of trade since more imports increase protectionism support, while people positively value exports, especially in small countries. Regarding policy measures, while protectionist measures do not influence protectionism support in general, easy access to exports reduces people's support for protectionism.
\end{abstract}

\section{Introduction}

Trade restriction levels applied by countries are strongly correlated with average support for protectionism among residents. But what elements shape these individuals' attitudes? Protectionism support depends not only on noneconomic factors such as values and demographic characteristics but also on the labour market and the macroeconomic situation. In this study, we examine some yet-to-be-studied factors that may influence opinions towards trade policies. We hypothesise that individual support for protectionism is not only affected by the above-mentioned factors but also by the macroeconomic context, importance of trade and size of the country, trade policies applied by the resident's country on its imports, and trade policies applied by other countries on exports of the resident's country.

The International Social Survey Programme (ISSP) survey of 2003, which is available for more than thirty countries, offers a good opportunity to study reasons for protectionism support. To investigate this issue, we explain protectionism support using an ordered probit model that includes individual attributes and country characteristics.

We build on the existing literature and bring new elements into the discussion. First, we test the influence of macroeconomic variables such as gross national income (GNI) per capita, inflation, unemployment rates, and risk index on individual attitudes. Second, we check if individual support for protectionism is in line with the predictions of comparative advantage models. Third, we study the link between import and export shares in GDP and individual opinions towards trade. Finally, we study how trade restrictions on imports influence individual attitudes and if access granted to country exports has an impact on his/her position. To anticipate our most important results, we find that individuals' opinions concerning protectionist policies match with how their revenue could be affected in the medium or long term. In turn, we find evidence that people's appreciation of the consequences of trade liberalisation for the whole economy is not in line with trade theory optimism for free trade. Finally, strengthening exports or access to export products reduces protectionist pressures.

The structure of the paper is as follows. In Section 2, we review the theory and evidence on protectionism support. In Section 3, we present an overview of the data used in this study and the hypotheses we aim to check. In Section 4, we present and discuss the results, while we draw conclusions in Section 5 . 


\section{Theoretical and Empirical Evidence concerning Protectionism Support}

2.1. How Should People React according to Trade Theory? Support for protectionism may therefore be explained by the impact of trade on individual income. Comparative advantage models explain how international trade affects personal income through changes in relative prices. The Heckscher-Ohlin model ( $\mathrm{H}-\mathrm{O})$ assumes complete costless factor mobility across sectors and is often presented as a long-run view. In contrast, the Ricardo-Viner model (R$\mathrm{V}$ ) assumes the existence of sector-specific factors and for this reason is often presented as a medium-term model. According to the H-O model, unskilled workers in unskilledlabour-abundant countries are expected to support free trade, while skilled workers would be expected to oppose it. The opposite would occur in skill-abundant countries. On the other hand, the R-V model predicts that specific factors of the importing sector will lose out from trade liberalisation, but factors specific to the export sector will gain from it. Given that labour is not very mobile across sectors in the short term, individual trade policy preferences will depend on whether the person is employed in an import-substituting or exporting industry [1].

Although empirical studies confirm that trade policy preferences depend on individuals' skills, the results of these studies are not fully in line with the H-O model. O'Rourke and Sinnott [2] and Baker [3] and Beaulieu et al. [4] find that skilled workers are more likely to accept free trade, regardless of their country's endowments. However, there is no consensus on this point. Mayda and Rodrik [5] find that in the Philippines (the poorest country in its sample), people with higher human capital endowment oppose free trade more than people with lower human capital endowment, while the opposite is true in richer countries such as Germany and the USA that are abundant in human capital. Beaulieu et al. [6] argue that the country sample in the ISSP database (see http://www.issp.org/) does not include a sufficient number of low-skilled countries to verify the $\mathrm{H}$ $\mathrm{O}$ hypothesis. In their study on Latin American countries, they find that skilled workers are less likely to oppose free trade in all countries. Furthermore, these studies showed that the differential in free trade support between skilled and unskilled workers is higher in countries that are relatively abundant in skilled labour. In turn, Sanz and Martínez-IComa [7] find more convincing results in favour of the $\mathrm{H}$ O model, although they focus on European citizens (in their study, skills favour protrade attitudes in countries which are more skill abundant than the sample average, while the opposite occurs in the rest of the countries). Verifications for the R-V model are scarce. Mayda and Rodrik [5] find that personal opinions are shaped by the trade exposure of their sector of employment. As the authors show, those employed in sectors with a comparative disadvantage tend to be more protectionist, while those working in nontradable sectors are the most likely to be in favour of freetrade.

2.2. How Macroeconomic Context Influences Protectionism Support? The literature focusing on the influence of the macroeconomic context on protectionism attitude is scarce. Denslow and Fullerton [8] point to the influence of risk aversion on people's attitudes. Using a consumer survey in Florida, they find that confidence about future national performance and education are the most important determinants of consumer attitudes towards trade policy. In the same line, Scheve and Slaughter [9] show that economic integration and foreign direct investment, in particular, have increased worker insecurity in the UK by increasing the volatility of wages and employment. This finding could partially explain people's attitudes towards free trade in the UK. Concerning the macroeconomic context, Beaulieu et al. [6] find that countries with higher support for trade tend to be countries that grew faster in the last decade. Caplanova et al. [10] analyse attitudes to EU membership among countries in central and eastern Europe. They find that good economic performance increases the probability of supporting membership.

Another relation that has received very little attention in the literature is how the trade balance situation or trade policies influence people's opinion towards these policies. As regards opinion polls, trade restriction levels are found to be strongly correlated with average support for protectionism among residents. Nevertheless, the direction of the causal relationship between preferences for protectionism and trade policies is not clear. Policymakers may design policies bearing in mind public opinion, that is, according to the "demand" side. Yet trade policies may, in turn, lead to biased attitudes towards trade policies. As suggested by Mayda and Rodrik [5], the "supply" side may also be important. They test the hypothesis that trade policies may influence individuals' attitudes in a nonuniform manner within a country, but did not find significant evidence to support it.

2.3. Other Factors Influencing Protectionism Support. Opinions towards trade policies are obviously linked to labor market's situation of respondents. People with higher educational levels anywhere in the world may be more flexible and more able to deal with the rigors of the market and therefore more likely to support trade liberalisation [11]. Rodrik [12] also suggested that globalisation tends to favour production factors that are internationally mobile. To the extent that skilled labour is more mobile than unskilled labour, skilled workers will be more optimistic about trade liberalisation, regardless of the relative abundance of skills in their country [2]. Additionally, the increase of skill premium within countries could also be explained by the skill-enhancing effect of trade. This is an additional reason to explain why skilled workers are generally expected to be more willing to support free trade (the study of Doyle and Fidrmuc [13] supports this view. They analyse support for EU membership in the new member and candidate countries of the EU in 2002. Their results suggest that individuals with relatively flexible human capital (those with high education, white-collar occupations, high income, etc.) tend to support EU membership. In contrast, those who may benefit from redistribution in the EU (the elderly, less educated, unemployed, etc.) tend to oppose accession).

Previous literature has demonstrated that trade policy preferences depend on noneconomic factors such as values 
and demographic characteristics. Concerning the influence of religious beliefs, Guiso et al. [14] argue that attitudes towards trade with "others" and accepting "others" differ across religious denominations. In their study for the USA, they find that Catholics, Baptists, and Methodists are more likely to support trade restrictions than those with no religious affiliation.

Undoubtedly, attachment to country and national pride matters in any debate concerning external policies. O'Rourke and Sinnott [2] state that these values play an important role in trade policy preferences due to the fact that such elements could translate into feelings of national superiority and the rejection of foreign products.

Finally, there are many demographic variables that may be relevant in explaining policy preferences. For example, in regard to age and gender, previous empirical studies have shown that the elderly are more likely to support import restrictive policies than younger people. The same can be said for women in comparison to men. Additionally, some empirical studies, [5] or [2], find that married people are also more likely to support trade restrictions.

\section{Data and Hypotheses}

3.1. Overview of Data. In this paper we use data from the National Identity module of the 2003 International Social Survey Program (ISSP) to study how the different characteristics of both individuals and countries affect support for protectionism. The ISSP is an ongoing effort devoted to cross-national research on social attitudes. The survey asks respondents about their opinions on a great variety of issues, including trade preferences. As previous studies have already shown, the ISSP survey allows the influence of social status, relative income, values, and attachments on preference formation to be explored (unfortunately, this question has not been included in the other waves of the survey. It is therefore impossible to run panel estimations or to study the evolution of the position of the same countries through time).

The respondents came from 33 countries across all five continents (Germany and Israel were included whole countries even though they are both included in the dataset as two regions. Due to the lack of data on income, South Africa and Venezuela were not included). The ISSP dataset provides a unique opportunity to verify all the hypotheses emerging from the previous review of the literature. Additionally, researchers can test if individuals react according to how specialisation affects their personal revenue. The survey also offers a less investigated possibility, namely, to verify to what extent the heterogeneity observed across individuals in their support for protectionism may be explained by some economic characteristics of their place of residence. We estimate ordered probit models in which the degree of protectionism support is explained by personal attributes as previous works do, and we also add important country characteristics.

The question used in the survey to identify respondents' trade preferences is "how much do you agree or disagree with the following statement: "Respondent's country" should limit the import of foreign products in order to protect its national economy." The dependent variable (PROTEC) that corresponds to the answer is coded as follows: three agree or strongly agree, two neither agree nor disagree, and one disagrees or strongly disagrees. Mayda and Rodrik [5] chose to transform the answer into a dummy variable (that equals one if people agree or strongly agree and zero otherwise). We opted for another possibility since we think that people who neither agree nor disagree should be considered as being more supportive for protectionism than people who disagree.

It could be argued that the last part of the question ("in order to protect its national economy") leads to biased responses in favour of protectionism as it implies that limiting imports is a way of protecting the economy and is therefore something positive. However, there are two arguments that partially detract from this criticism. Firstly, this is the usual manner of speech employed to defend protectionist policies and thus the normal terms used to discuss the matter. Hence, this question would not necessarily induce the respondent to answer in a particular way. And secondly, because the goal of this paper is to analyse the relationship between this variable and others and not to estimate the absolute level of support for protectionism, our analysis is less vulnerable to this type of bias [2].

On average, about 1,000 people have answered the survey in each country, obtaining a total of 42,154 observations. Table 1 shows the distribution of answers for each country. The share of people supporting protectionism ranges from 28.9 per cent (in Sweden) to 76.4 per cent (in Bulgaria). The share of people who clearly disagree or strongly disagree with protectionism measures rarely exceeds 30 per cent except for Switzerland (43 per cent), Sweden (35 per cent), Norway (36 per cent), and Denmark (48 per cent). It is striking that these last three countries are neighbours and have similar political systems with a high level of state intervention.

3.2. Hypotheses concerning Personal Attributes. Concerning personal attributes, we include earnings in logarithms (log of income) and a subjective evaluation by the individual regarding his or her social status (upper class). We expect both variables to decrease the probability of supporting protectionism. In turn, patriotism and nationalism (pride and chauvinism) are expected to increase support for protectionism. As concerns demographic variables, we consider age (age and age ${ }^{2}$ ) and gender (female), which usually strengthen the protectionist view. We hypothesise that personal skill (measured by years of schooling) generally decreases support for protectionism. Note that our sample includes high, middle, and lower-middle income countries (according to the World Bank classification, Atlas Method). Our sample is less biased towards rich countries than the 1995 ISSP used in Mayda and Rodrik [5], though we cannot consider that we have a representative sample of poor countries. A complete description of the variables is provided in Table 2.

\subsection{Hypotheses and Evidence concerning the Influence of} Macroeconomic Context. To the end that products including a higher level of capital per worker are more willing to operate under increasing returns, we expect richer countries 
TABLE 1: Answers by country.

\begin{tabular}{|c|c|c|c|c|}
\hline Country & $\begin{array}{l}\text { ISO3 } \\
\text { code }\end{array}$ & No protect & Protect & Neutral \\
\hline $\begin{array}{l}\text { Australia } \\
\text { (omitted) }\end{array}$ & AUS & 14.5 & 66.1 & 19.4 \\
\hline Austria & AUT & 23.5 & 58.8 & 17.7 \\
\hline Bulgaria & BGR & 11.5 & 76.4 & 12.1 \\
\hline Canada & CAN & 26.2 & 51.4 & 22.4 \\
\hline Chile & $\mathrm{CHL}$ & 21.9 & 63.5 & 14.6 \\
\hline Czech-Republic & CZE & 27.1 & 50.6 & 22.2 \\
\hline Denmark & DNK & 48.1 & 35.6 & 16.4 \\
\hline Finland & FIN & 38.4 & 34.0 & 27.6 \\
\hline France & FRA & 27.8 & 51.7 & 20.5 \\
\hline Germany & DEU & 33.0 & 44.3 & 22.7 \\
\hline Great Britain & GBR & 16.2 & 59.4 & 24.3 \\
\hline Hungary & HUN & 13.3 & 65.3 & 21.4 \\
\hline Ireland & IRL & 27.6 & 57.7 & 14.7 \\
\hline Israel & ISR & 22.4 & 62.7 & 14.9 \\
\hline Japan & JPN & 28.4 & 40.8 & 30.8 \\
\hline Latvia & LVA & 15.9 & 66.9 & 17.2 \\
\hline New Zealand & $\mathrm{NZL}$ & 21.3 & 57.0 & 21.7 \\
\hline Norway & NOR & 36.4 & 35.1 & 28.5 \\
\hline Philippines & PHL & 11.6 & 72.7 & 15.7 \\
\hline Poland & POL & 12.1 & 71.9 & 15.9 \\
\hline Portugal & PRT & 21.6 & 63.8 & 14.6 \\
\hline Russia & RUS & 20.2 & 63.6 & 16.2 \\
\hline Slovak Republic & SVK & 9.5 & 65.8 & 24.7 \\
\hline Slovenia & SVN & 28.3 & 52.9 & 18.8 \\
\hline South Korea & KOR & 24.7 & 52.6 & 22.7 \\
\hline Spain & ESP & 14.7 & 59.5 & 25.8 \\
\hline Sweden & SWE & 35.3 & 28.9 & 35.8 \\
\hline Switzerland & $\mathrm{CHE}$ & 43.4 & 36.7 & 19.9 \\
\hline United States & USA & 17.2 & 61.4 & 21.4 \\
\hline Uruguay & URY & 13.0 & 73.1 & 13.9 \\
\hline
\end{tabular}

Source: ISSP, values in percentages.

to obtain more gains from trade. We include Gross National Income per capita (LGNIPC) to reflect the average income of inhabitants. LGNIPC is also a proxy for the stock of capital per worker. Countries with a higher GNI per capita also display a larger share of intraindustry trade. As pointed out by Helpman and Krugman [18], the income redistribution effects of intraindustry trade are considerably less traumatic than those of interindustry trade. According to this new trade theory, support for free trade should be higher in countries that are more involved in intraindustry trade. Indeed, Beaulieu et al. [4] find that support for trade by skilled workers is systematically higher in countries with a higher level of intraindustry trade. Verifying this proposal for a large sample of countries would be very costly in terms of data. Since richer countries also trade more on an intraindustry basis, this is another reason why we expect LGNIPC to have a negative effect on protectionist views.
Figure 1 offers a first overview of the relationship between the amount of people supporting protectionist policies and GNI per capita. Average support for protectionism clearly decreases as GNI per capita increases. We detect some outliers like the USA, which reveal stronger support for protectionism than that predicted by the GNI per capita, while the opposite occurs for Sweden.

As business cycles may influence respondents' sensitivity to trade policies, variations of inflation (LCPIVAR) and unemployment rates (LUNEMPVAR) are also included. Inflation can influence individuals in several manners. On the one hand, as a growing inflation rate reflects an uncertain macroeconomic context, the risk aversion of residents may grow and negatively affect their willingness to accept new adjustments caused by the dismantling of trade restrictions. On the other hand, the removal of trade restrictiveness decreases the price of imported products and the general level of prices in the economy so people may wish to remove protectionist measures in this context. Although the way inflation rate impacts individual trade policy preferences is undetermined, a negative sign would indicate that individuals are aware of free trade benefits in lower prices, while a positive sign would denote that the fear of adjustment costs in an unstable macroeconomic context prevails.

Finally, Denslow and Fullerton [8] show that uncertainty, competition risks, and other cyclical factors play a relevant role in determining people's attitudes towards free trade. Scheve and Slaughter [9] add that labour insecurity (measured by the volatility of wages) tends to favour proprotectionism attitudes. In line with these findings and in order to assess the influence of economic instability in a larger sample, we include an indicator of risk market (RISK) provided by SACE (an Italian insurance and financial group) (see http://www.sace.it/GruppoSACE/content/ it/index.html). The index covers political and commercial risk in over 180 countries. Among the political and commercial factors, it considers (1) expropriation risk, (2) political violence risk, (3) transfer risk, (4) economic risk, (5) financial risk, and (6) operational risk.

3.4. How Should People React according to Trade Theory? We need to verify if the people in our sample react according to the $\mathrm{H}-\mathrm{O}$ and $\mathrm{R}-\mathrm{V}$ theories. In order to check the StolperSamuelson theorem hypothesis, we interact the variable EDUCYRS with the logarithm of per capita GDP as in Mayda and Rodrik [5]. Unlike these authors, we also include the LGNIPC variable as recommended by Ai and Norton [19] and interpret the interacted variable (EDUIPC) jointly with the coefficients of EDUCYRS depending on LGNIPC level. We expect a decreasing effect of education on protectionism view as GNI per capita increases.

In order to test the predictions of the $\mathrm{R}-\mathrm{V}$ models, we reclassify the information concerning the individual's occupation (in the ISSP survey, this information is coded according to the International Statistical Comparisons of Occupational and Social Structures (ISCO-88) and provides information about the occupation but not directly about the industry. In most cases, the classification indicates the industry (i.e., "glass, ceramics and related plant operators"), 
TABLE 2: Description of variables.

\begin{tabular}{|c|c|c|}
\hline Variable name & Variable label & Data source \\
\hline $\mathrm{ADV}$ & 1 if employment sector comparative advantage is strong & $\begin{array}{l}\text { ISSP }(2003) / \\
\text { CEPII [15] }\end{array}$ \\
\hline Age & Respondent's age & ISSP (2003) \\
\hline $\mathrm{Age}^{2}$ & Age $*$ Age & ISSP (2003) \\
\hline Agriculture & 1 if working in agricultural sector & ISSP (2003) \\
\hline Attend religion & 1 if attends religious services once a week or more & ISSP (2003) \\
\hline Chauvinism & $\begin{array}{l}1 \text { if agreeing with "generally speaking, your country is a better country than most other } \\
\text { countries" }\end{array}$ & ISSP (2003) \\
\hline CAI & Comparative Advantage Index, mean 1980-2001 & $\begin{array}{l}\text { ISSP } \\
(2003) / C E P I I \\
{[15]}\end{array}$ \\
\hline CPI (change) & Logarithm of $(1+$ the change in inflation rate $)$ & World Bank [16] \\
\hline DADV & 1 if employment sector comparative disadvantage is strong & $\begin{array}{l}\text { ISSP } \\
(2003) / C E P I I \\
{[15]}\end{array}$ \\
\hline EDUYEARS & Years of schooling & ISSP (2003) \\
\hline EDUIPC & EDUYEARS * LGNIpc & $\begin{array}{l}\text { ISSP }(2003) / \\
\text { World Bank [16] }\end{array}$ \\
\hline Female & 0 for men and 1 for women & $\operatorname{ISSP}(2003)$ \\
\hline High & 1 if LGNIpc is higher than 9.2 (equivalent to US\$10,000) & World Bank [16] \\
\hline Industry & 1 if working in industrial sector & ISSP (2003) \\
\hline Large & 1 if the number of inhabitants is higher than 30 million & World Bank [16] \\
\hline LGNIpc & Logarithm of Gross National Income per capita, Atlas method (current US\$) & World Bank [16] \\
\hline LINCOME & Logarithm of earnings & ISSP (2003) \\
\hline LMAOTRI & $\begin{array}{l}\text { Logarithm of Market Access Overall Trade Restrictiveness Index (tariffs and nontariff } \\
\text { barriers) }\end{array}$ & $\begin{array}{l}\text { Anderson and } \\
\text { Neary [17] }\end{array}$ \\
\hline LMRATIO & Logarithm of imports of goods and services (percentage GDP, 2000-2004 average) & World Bank [16] \\
\hline LOTRI & Logarithm of Overall Trade Restrictiveness Index (tariffs and nontariff barriers) & $\begin{array}{l}\text { Anderson and } \\
\text { Neary [17] }\end{array}$ \\
\hline LXRATIO & Logarithm of exports of goods and services (percentage GDP, 2000-2004 average) & World Bank [16] \\
\hline Middle & 1 if LGNIpc is lower than 9.2 (equivalent to US\$10,000) & World Bank [16] \\
\hline Pride & 1 if feeling proud of country & ISSP (2003) \\
\hline Risk & Logarithm of country risk & SACE (2004) \\
\hline Service & 1 if working in service sector & ISSP (2003) \\
\hline Small & 1 if the number of inhabitants is 30 million or lower & World Bank [16] \\
\hline Trade & Logarithm of external balance of payments as percentage of GDP & World Bank [16] \\
\hline $\begin{array}{l}\text { Unemployment rate } \\
\text { (change) }\end{array}$ & Logarithm of $(1+$ the change in unemployment rate $)$ & World Bank [16] \\
\hline Upper class & 1 if self-placement on 10-point income scale is between 6 and 10 & ISSP (2003) \\
\hline
\end{tabular}

but for some occupations we only know if the individual works in agriculture, manufacturing or services as "managers of small enterprises in manufacturing." We were therefore unable to assign them to a more detailed manufacturing industry.) into three productive sectors: agriculture, industry, and services. Since industrial and agricultural products are more easily traded than services, we expect people working in nontrading sectors to be more likely to favour free trade than other people. Since workers in the agricultural sector are assumed to be less mobile than those working in the industrial sector and due to the higher level of protection in this sector, it seems to be that people working in agriculture are more protectionist than those working in industry. We also classify agricultural and industrial activities into activities with comparative advantages and disadvantages as indicated by the CEPII CHELEM database for the year 2003. According to the R-V model, we expect higher protectionist support among people working in sectors with comparative disadvantages, whereas the opposite should occur for people working in sectors with comparative advantages. 


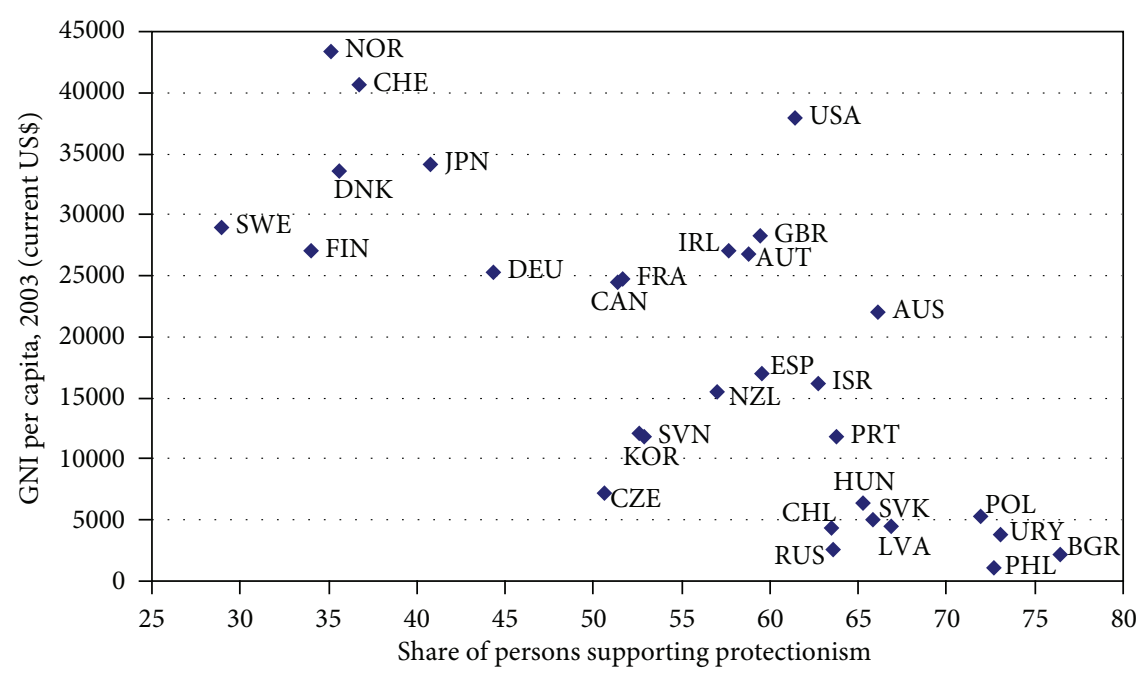

FIGURE 1: Share of persons supporting protectionism and GNI per capita. Note: ISO3 country abbreviations are reported in Table 1.

3.5. Influence of Trade on Protectionist View. The impact of trade balance on protectionist views has not yet been studied. We argue that a high import penetration rate (MRATIO) could reflect a large level of dependency on foreign products and should be associated with strong support for liberalisation. However, the relationship between imports and proprotectionism may be more complex. The MRATIO also depends on trade policies. That is, a low penetration rate can reflect a very strong protectionist policy. In this case, a lower MRATIO may increase support for protectionism. In both of the previous cases, the relationship between MRATIO and PROTEC should be negative. In turn, if the presence of foreign products in the domestic market is perceived as an invasion of the domestic market, it may increase the demand for a protectionist policy. In this case, the relationship between MRATIO and PROTEC would be positive.

In the same line, the export ratio (XRATIO) has not been accounted for in the related literature. As far as national protectionist measures can be seen as a counterpart to the difficulties of exporting, a lower XRATIO should increase the support for protectionism.

The MRATIO is introduced to reflect the dependency of the country on international products from the demand side. XRATIO reflects the dependency of the country on international products from the supply side. MRATIO and XRATIO were obtained from the World Bank Database and included in log terms. In Figure 2, we see that the relationship between importing goods and services and the share of protectionist individuals is not as clear as for the GNI per capita. Strong heterogeneity is found among countries with a penetration rate of around 40 per cent.

3.6. Influence of Trade Policies on Protectionist View. We use the Overall Trade Restrictiveness Index (OTRI, in logs) and Market Access Index (MAOTRI, in logs) calculated by Anderson and Neary [17]. These indices, respectively, reflect the restrictiveness of trade policy in the respondent's country, as well as the barriers placed on goods from the respondent's country in the foreign market. The indices take into account tariffs and nontariff barriers imposed by a country in a multilateral context and how these barriers affect a country's imports and exports. A high OTRI for country $\mathrm{X}$ denotes that country $\mathrm{X}$ highly restricts the imports of foreign products, while a high MAOTRI for country $\mathrm{X}$ indicates that country X's exports face high barriers in foreign markets. Unfortunately, these indices are only available at the aggregate level and not for sectors.

The relationship between trade policy instruments and protectionism support is not homogeneous (Figure 3). While countries that apply higher barriers to trade also show strong support for protectionism, we observe important differences among EU members, though the overall restrictiveness index for the EU seems to be correlated with the average support for protectionism shown by its members. Heterogeneity is also striking among countries with lower barriers.

In highly protected economies, people may value the inconveniences of such policies more highly or, in contrast, they may fear the costs of liberalisation. The expected sign for the coefficient of OTRI is thus undetermined. Additionally, since restrictive policies are explained to a larger extent by high protectionism support, this index may suffer an endogenous bias. We also control for this possible bias using instrumental variables for OTRI. Concerning MAOTRI, it is likely that residents in the exporting country will unanimously consider the effect of better access to international markets as being positive. Yet their level of awareness about these measures and how far this sentiment is connected to their support for national protectionism is less clear. If support for protectionism increases (significant positive sign) when there are difficulties to export, it will demonstrate that exports are viewed as a counterweight to the removal of national restrictions.

\section{Results}

In this section we study the impact of different individual and country characteristics on individual protectionism 


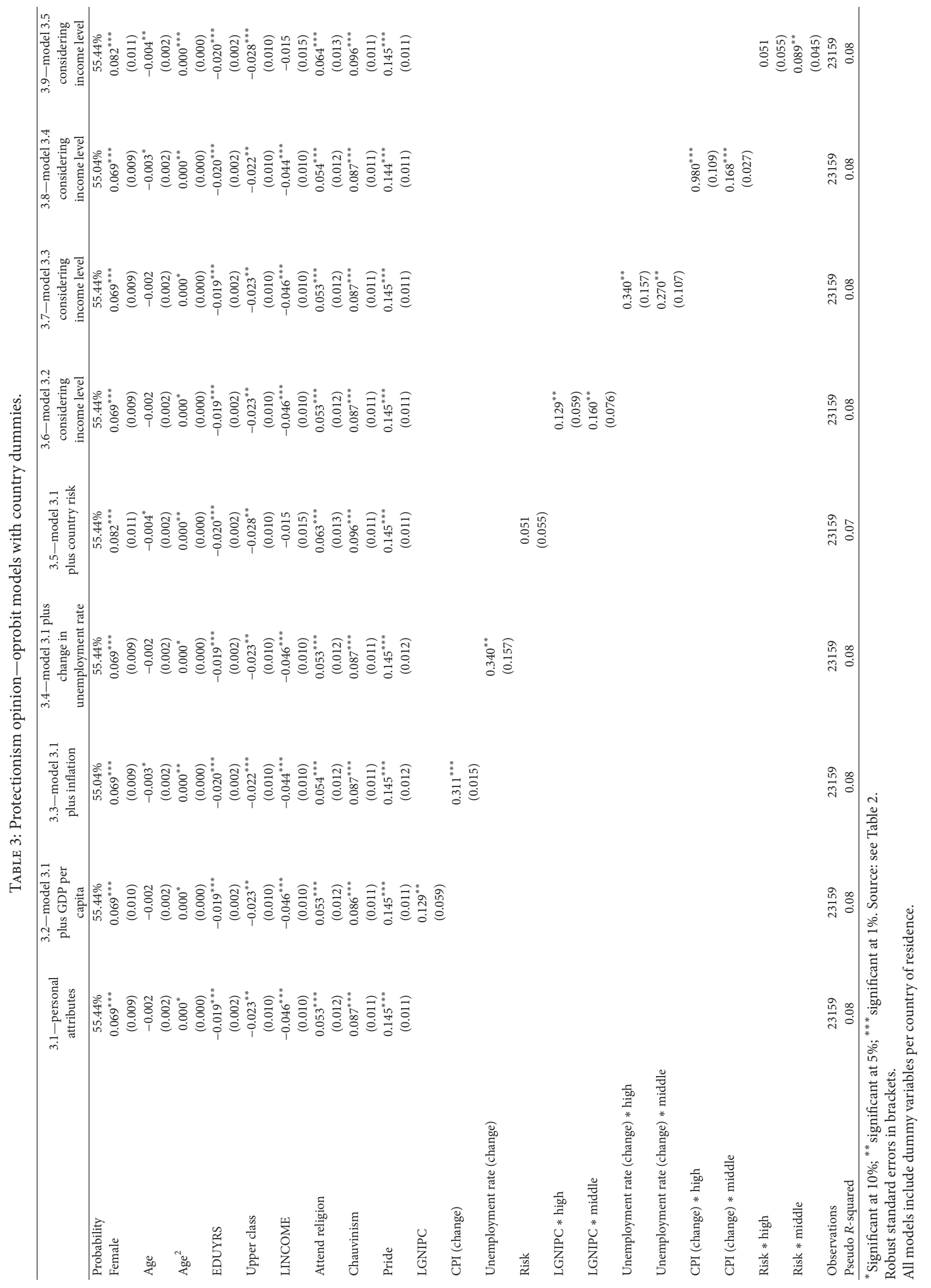




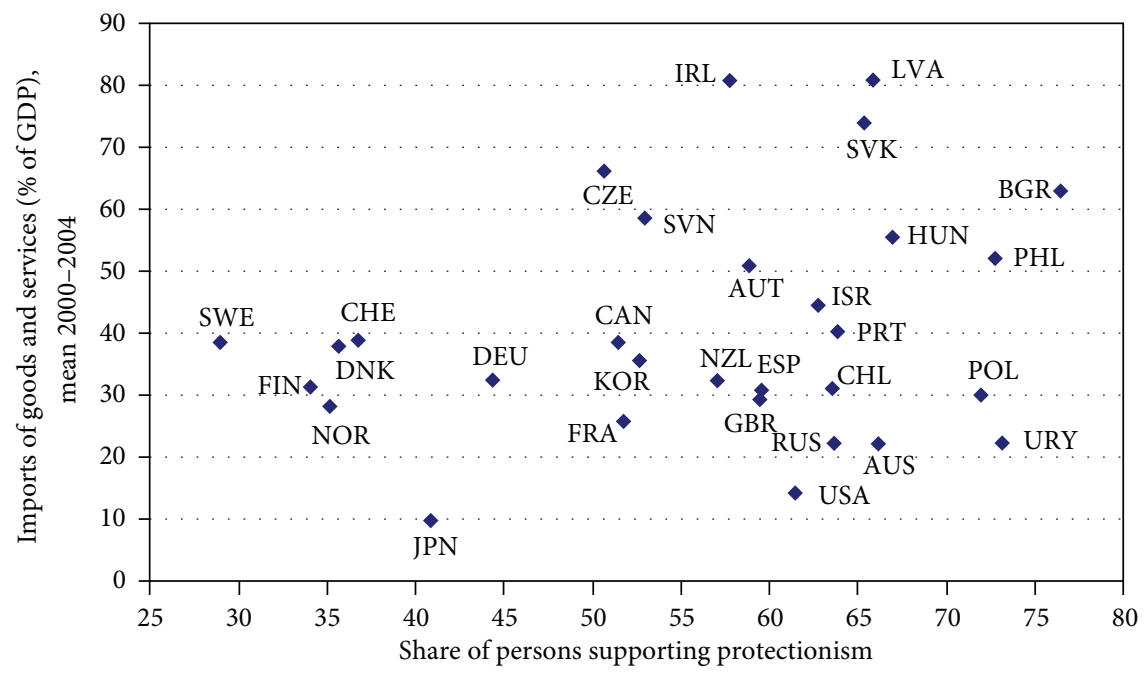

FIGURE 2: Share of persons supporting protectionism and import penetration. Note: ISO3 country abbreviations are reported in Table 1.

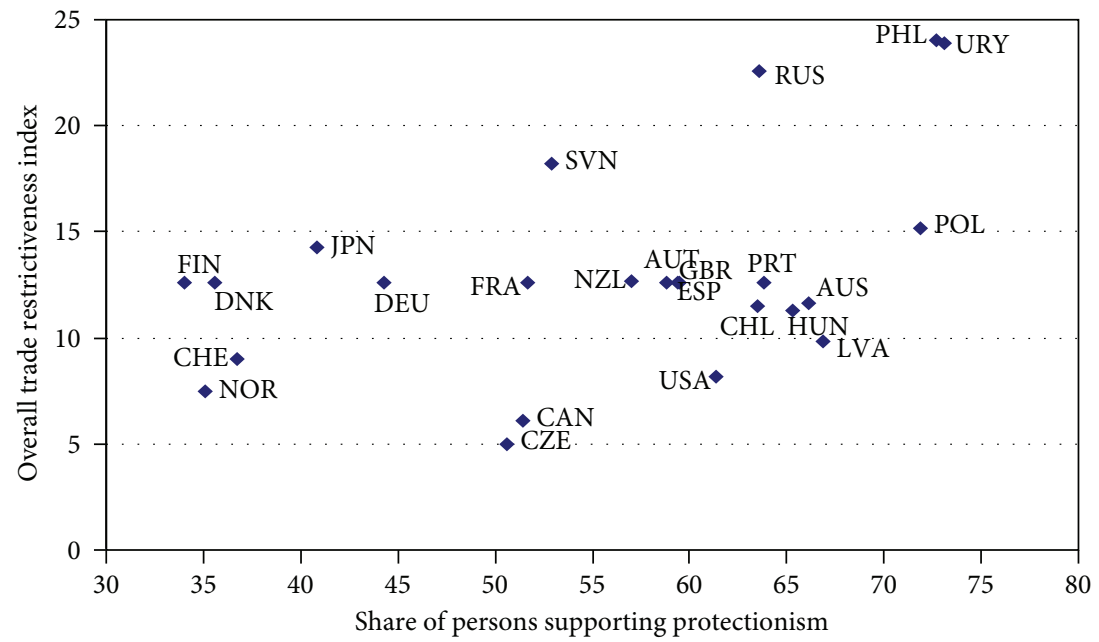

FIGURE 3: Share of persons supporting protectionism and trade policy. Note: ISO3 country abbreviations are reported in Table 1.

support. Our results concerning the influence of personal characteristics are standard. Specifically, we find that people with the characteristics "religious attendance", "low social status," "low personal income," "pride," "chauvinism," and "female" are more prone to support protectionist policies. Unlike other studies, we find that age, when significant, decreases protectionism support and the coefficient of age squared is almost zero, indicating that this effect is constant. In general, our conclusions are similar to those of Daniels and von der Rhur [20] and Mayda and Rodrik [5] among others, who concluded that social status, relative income, values, and attachments have a noticeable influence on the formation of preferences. Like these studies, we also provide evidence that protrade preferences are positively and robustly correlated with individuals' level of human capital.

Since these results are well known, in what follows we focus on the impact of country characteristics on individual support for protectionism, the most original contribution of our study. The influence of macroeconomic variables is discussed in Section 3.2. We provide an empirical verification for the predictions of the comparative advantage models and new trade theory in Section 3.3. Finally, Section 3.4 analyses the impact of trade policy.

4.1. How Does Macroeconomic Context Influence Individual Attitudes towards Protection? Table 3 presents the results of a series of regressions that explain support for protectionism. It is commonly accepted that country-specific factors influence individuals' attitudes towards trade policies. For this reason, all models include country dummies. Model 3.1 does not include any macroeconomic indicators, while in models 3.2 to 3.5 we include GNI per capita, variation of inflation rate, variation of unemployment rate, and global market risk indicator for the respondents' countries, respectively. Including these macroeconomic indicators does not, in general, alter the sign and significance of the parameters for individual 


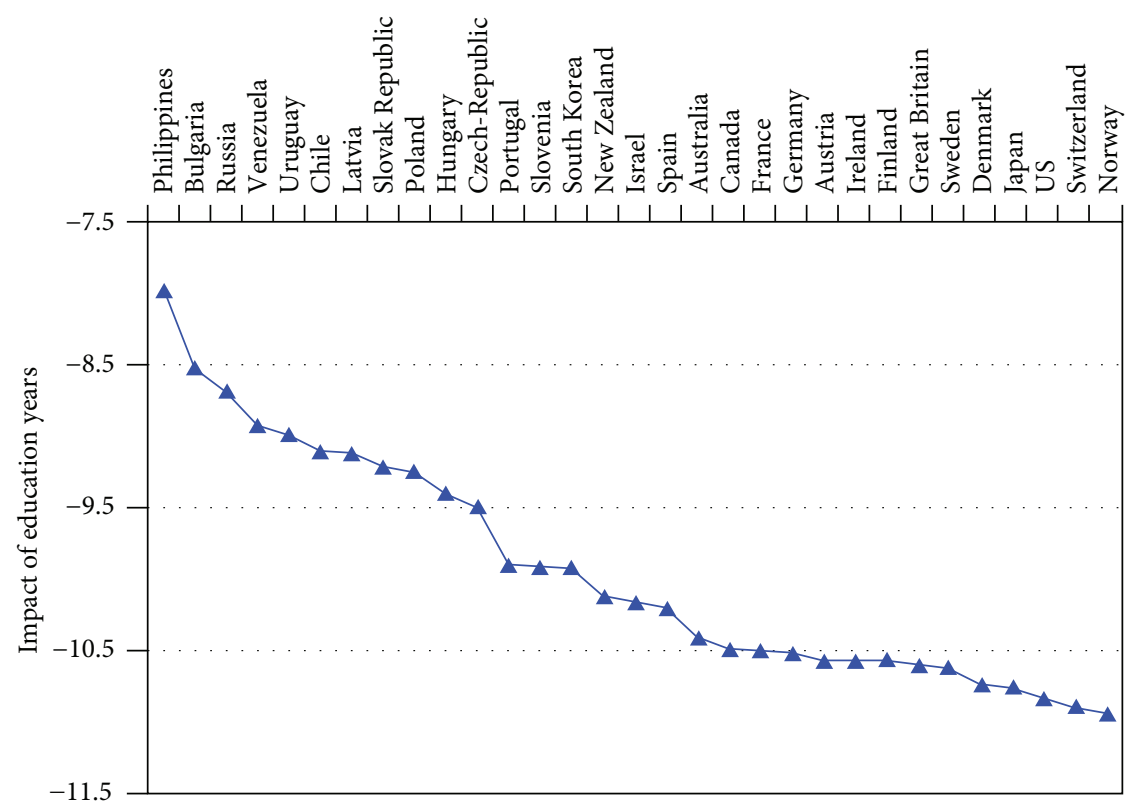

FIGURE 4: Interaction effect between education and gross domestic product (per capita, in logs).

characteristics. We check if macroeconomic variables affect the protectionism view in high and low income countries in a different way. To this end, we interact the variable of interest with a dummy that indicates if the respondent's country is classified as a high- or middle-income country.

We reach the unexpected results that support for protectionist measures increases with the GNI per capita of the country once country specificity is controlled for. The same result is obtained when we take into account the growth rate of the GNI per capita instead of the level. Thus, GNI per capita turns negative when we drop dummies for countries (these results are not reported here, but are available upon request). Therefore, people in rich countries are less likely to offer support for the protectionist view, although this is already taken into account with the countries' dummies.

Our results show that support for protectionism increases when inflation pressures become high despite the fact that trade liberalisation would rationally push prices down. It therefore seems that inflation rate, insofar as it reflects macroeconomic instability, may increase protectionism pressure. An increase in unemployment rate also increases protectionist attitudes. These results confirm that the business cycle influences opinions towards trade policies. A large increase in unemployment rate or inflation rate increases protectionist attitudes, especially in high-income countries.

In turn, we find that the global market risk index has no statistically significant effect, thus indicating that neither free trade nor protectionism is viewed as a solution for market instability. In turn, protectionism is viewed as a solution when market risk increases in middle-income countries.

4.2. Do Trade Theory Predictions Shape Protection Opinions? In Table 4 we present several tests for trade model predictions. In model 4.4, we test the direct predictions of the $\mathrm{H}-\mathrm{O}$ model.
In order to check the Stolper-Samuelson theorem hypothesis, we interact the variable EDUCYRS with the logarithm of per capita GDP as in Mayda and Rodrik [5]. Unlike these authors, we also include the variable GNIPC as recommended by Ai and Norton [19]. Following these authors, the coefficients for the interacted variable (EDUIPC) should be interpreted jointly with the coefficient of GNIPC and EDUCYRS. EDUCYRS and EDUIPC present a negative sign, while GNIPC presents a positive sign. This means that below a given GNIPC threshold level, education increases support for protectionism, while under a given GNIPC threshold level, low-skilled individuals are more reticent towards free trade. Consequently, we expect that education will increase protectionist support in countries such as the Philippines (the lowest GNIPC) and, on the opposite side, educated people in richer countries like Switzerland or Norway will tend to favour free trade. Our results are presented in Figure 4 and they confirm that individuals take into account the redistributive effect of trade. Finally, our results confirm that education reduces the probability of supporting restrictions on imports. The impact of education is larger in high-income countries than in middle-income countries.

We test several predictions in line with the R-V model. In model 4.6 we include dummies for the respondents' activity sector (agriculture, industry, and services). Surprisingly, we find that all three sectors have a significant positive impact, suggesting that workers are, on average, more supportive of protectionist measures than nonworkers. Specifically, we expected people working in the services sector not to be protectionist. Nonetheless, the marginal effects of these variables are more in line with our predictions since the highest impact is found in the case of agriculture (generally more protected) followed by industry and services. Interacting the variables of the employment sector with dummies indicating 
TABle 4: Protectionism opinion-verification of trade theory predictions.

\begin{tabular}{|c|c|c|c|c|c|}
\hline & $\begin{array}{l}\text { 4.1-interaction } \\
\text { effects, H-O model }\end{array}$ & $\begin{array}{l}4.2 \text { - the effects of } \\
\text { education per country size }\end{array}$ & $\begin{array}{l}\text { 4.3- with activity } \\
\text { sectors }\end{array}$ & $\begin{array}{l}\text { 4.4-with comparative } \\
\text { advantage index }\end{array}$ & $\begin{array}{c}\text { 4.5-with } \\
\text { comparative } \\
\text { (dis)advantage }\end{array}$ \\
\hline Probability & $55.38 \%$ & $55.4 \%$ & $55.79 \%$ & $55.44 \%$ & $55.44 \%$ \\
\hline \multirow[t]{2}{*}{ EDUYRS } & $-0.024^{* *}$ & $-0.024^{* *}$ & $-0.018^{*}$ & $-0.023^{* *}$ & $-0.023^{* *}$ \\
\hline & $(0.010)$ & $(0.010)$ & $(0.010)$ & $(0.010)$ & $(0.010)$ \\
\hline \multirow[t]{2}{*}{ LGNIPC } & $0.250^{* * *}$ & & & & \\
\hline & $(0.064)$ & & & & \\
\hline \multirow[t]{2}{*}{ EDUIPC } & $-0.008^{* * *}$ & & & & \\
\hline & $(0.002)$ & & & & \\
\hline \multirow[t]{2}{*}{ EDUYRS $*$ high } & & $-0.023^{* * *}$ & & & \\
\hline & & $(0.002)$ & & & \\
\hline \multirow[t]{2}{*}{ EDUYRS $*$ middle } & & $-0.008^{* *}$ & & & \\
\hline & & $(0.004)$ & & & \\
\hline \multirow[t]{2}{*}{ Industry } & & & $0.049^{* * *}$ & & \\
\hline & & & $(0.015)$ & & \\
\hline \multirow[t]{2}{*}{ Agriculture } & & & $0.117^{* * *}$ & & \\
\hline & & & $(0.039)$ & & \\
\hline \multirow[t]{2}{*}{ Service } & & & $0.026^{* *}$ & & \\
\hline & & & $(0.013)$ & & \\
\hline \multirow[t]{2}{*}{ CAI } & & & & $-0.001^{* *}$ & \\
\hline & & & & $(0.000)$ & \\
\hline \multirow[t]{2}{*}{$\mathrm{ADV}$} & & & & & 0.012 \\
\hline & & & & & $(0.025)$ \\
\hline \multirow[t]{2}{*}{ DADV } & & & & & $0.060^{* * *}$ \\
\hline & & & & & $(0.016)$ \\
\hline Observations & 23159 & 23159 & 23159 & 23159 & 23159 \\
\hline Pseudo $R$-squared & 0.08 & 0.08 & 0.08 & 0.08 & 0.08 \\
\hline
\end{tabular}

${ }^{*}$ Significant at $10 \% ;{ }^{* *}$ significant at $5 \% ;{ }^{* * *}$ significant at $1 \%$. Source: see Table 2.

Robust standard errors in brackets.

All models 3.2 include dummy variables per country of residence.

All models include the same set of control variables not included in Table 3 (female, age, age ${ }^{2}$, upper class, lincome, attend religion, chauvinism, pride).

the country, we obtain that protectionist attitudes in the agricultural sector mainly come from people employed in this sector in small countries.

To test the $\mathrm{R}-\mathrm{V}$ model more precisely, in model 4.6 and model 4.7 we account for the comparative advantage or disadvantage (calculated in reference to the world trade structure) of the sector in which the respondents are working. Firstly, we consider a continuous variable, the Comparative Advantage Index. Secondly, we build two dummies corresponding to the comparative advantage and comparative disadvantage cases. The results show that working in a sector with a comparative advantage decreases protectionist support, while working in a disadvantaged sector has a positive and significant effect. Our results unambiguously support the $\mathrm{R}-\mathrm{V}$ model, which is often presented as a medium-term view of trade effects.
4.3. How Does Trade Affect Support for Protectionism? The intensity of international trade integration may play an important role in the way citizens shape their preferences towards trade policies. In what follows, we turn to the influence of international trade on protectionist opinions. The results shown in Table 5 confirm that the share of foreign products in national production significantly increases individual support for protectionist policies. In the same line, we observe that a greater export ratio or a larger trade balance relaxes protectionist pressures.

Larger markets could benefit from a market power that enables them to increase their term of trade by increasing the static gains of protection. In contrast, inhabitants of small countries could be aware of their dependency on foreign products and more reluctant to use protectionist measures even when external trade represents a large share of their 
TABLE 5: Trade impact on individual opinion towards protectionism.

\begin{tabular}{|c|c|c|c|c|}
\hline & $\begin{array}{l}5.1 \text {-import penetration } \\
\text { rate and export ratio }\end{array}$ & $\begin{array}{c}5.2 \text {-balance of } \\
\text { payments }\end{array}$ & $\begin{array}{c}5.3 \text { - model } 5.1 \\
\text { considering country size }\end{array}$ & $\begin{array}{c}5.4-\text { model } 5.2 \\
\text { considering country size } \\
\end{array}$ \\
\hline & $55.44 \%$ & $55.44 \%$ & $55.44 \%$ & $55.44 \%$ \\
\hline \multirow[t]{2}{*}{ EDUYRS } & $-0.019^{* * *}$ & $-0.019^{* * *}$ & $-0.019^{* * *}$ & $-0.019^{* * *}$ \\
\hline & $(0.002)$ & $(0.002)$ & $(0.002)$ & $(0.002)$ \\
\hline \multirow[t]{2}{*}{ LXRATIO } & $-0.867^{* * *}$ & & & \\
\hline & $(0.161)$ & & & \\
\hline \multirow[t]{2}{*}{ LMRATIO } & $0.882^{* * *}$ & & & \\
\hline & $(0.212)$ & & & \\
\hline \multirow[t]{2}{*}{ Trade } & & $-0.102^{* *}$ & & \\
\hline & & $(0.045)$ & & \\
\hline \multirow[t]{2}{*}{ LXRATIO $*$ large } & & & -0.122 & \\
\hline & & & $(0.141)$ & \\
\hline \multirow[t]{2}{*}{ LXRATIO $*$ small } & & & $-0.655^{* * *}$ & \\
\hline & & & $(0.144)$ & \\
\hline \multirow[t]{2}{*}{ LMRATIO $*$ large } & & & -0.222 & \\
\hline & & & $(0.170)$ & \\
\hline \multirow[t]{2}{*}{ LMRATIO $*$ small } & & & $0.367^{* *}$ & \\
\hline & & & $(0.173)$ & \\
\hline \multirow[t]{2}{*}{ Trade $*$ large } & & & & $-0.296^{* * *}$ \\
\hline & & & & $(0.033)$ \\
\hline \multirow[t]{2}{*}{ Trade $*$ small } & & & & $-346.662^{* * *}$ \\
\hline & & & & $(93.516)$ \\
\hline Observations & 23159 & 23159 & 23159 & 23159 \\
\hline Pseudo $R$-squared & 0.08 & 0.08 & 0.08 & 0.08 \\
\hline
\end{tabular}

economic activity. To test this hypothesis, in models 5.3 and 5.4 we interact MRATIO, XRATIO, and TRADE with dummies indicating the size of the country. Our results confirm that the presence of foreign products or the importance of export activities is decisive for inhabitants of small countries, but not so important for people living in large countries. Trade deficit increases protectionist views, particularly in these small countries.

4.4. How Do Trade Policies Affect Support for Protectionism? In our benchmark model we include trade policy indicators (Table 6). Restrictions on imports have no significant effect on support for free trade. Our results show that these measures do not affect individuals' attitudes in a uniform manner. As explained above, it could be argued that OTRI is also influenced by inhabitants opinions towards trade policies and should be considered as an endogenous variable. To control for this bias, we instrument OTRI using variables that may affect the decision to restrain trade at the macroeconomic level (these instruments should not be correlated with the characteristics affecting individuals' opinions, which are not taken into account in the main equation. That is, we must select variables that are not correlated with the residuals of the ordered probit equation. The selected country attributes may reflect the situation of the business cycle as well as some structural characteristics of the country's production that may explain its balance of payments. Namely, we include inflation; growth rate; shares of agriculture, services and industry in the GDP; MAOTRI; and indicators of the income and debt group. The results for the first equation are highly significant. All the coefficients are significant at the one per cent level. These coefficients are as follows: OTRi = $0.003 *$ INFLATION $-0.002 *$ GDP_GROWTH -0.176 * LMAOTRI + 8.420*VA_AGR + 8.416*VA_IND + $8.3416 *$ VA_SER $+-0.020 *$ INCOME_GROUP $+0.032 *$ DEBT_GROUP - 841.476. To a lesser extent, this argument also applies for MRATIO since attitude indirectly affects trade policy, which in turn affects imports. We also estimate models where the MRATIO is instrumentalised. The results are similar to those presented here and available upon request). Once corrected for endogenous bias, the results confirm that the more protectionist the respondent's country, the higher the support for protectionism. In the same line, the higher the restrictions imposed on national 
TABLE 6: Trade policy impact on individual opinion towards protectionism.

\begin{tabular}{|c|c|c|c|c|}
\hline & $\begin{array}{l}6.1 \text {-overall trade } \\
\text { restrictiveness index and } \\
\text { market access index }\end{array}$ & $\begin{array}{c}6.2 \text {-model } 6.1 \\
\text { plus OTRI } \\
\text { instrumented }\end{array}$ & $\begin{array}{c}\text { 6.3-overall trade restrictiveness } \\
\text { index considering country size } \\
\text { and market access index }\end{array}$ & $\begin{array}{l}\text { 6.4-overall trade restrictiveness } \\
\text { index and market access index } \\
\text { considering country size }\end{array}$ \\
\hline Probability & $55.08 \%$ & $55.85 \%$ & $55.08 \%$ & $55.05 \%$ \\
\hline \multirow[t]{2}{*}{ EDUYRS } & $-0.020^{* * *}$ & $-0.020^{* * *}$ & $-0.020^{* * *}$ & $-0.020^{* * *}$ \\
\hline & $(0.002)$ & $(0.002)$ & $(0.002)$ & $(0.002)$ \\
\hline \multirow[t]{2}{*}{ LOTRI } & 0.447 & & & $1.349^{* *}$ \\
\hline & $(0.341)$ & & & $(0.646)$ \\
\hline \multirow[t]{2}{*}{ LMAOTRI } & $0.975^{* * *}$ & $17.505^{* * *}$ & $0.677^{*}$ & \\
\hline & $(0.166)$ & $(4.542)$ & $(0.395)$ & \\
\hline \multirow[t]{2}{*}{ LOTRI instrumented } & & $33.145^{* * *}$ & & \\
\hline & & $(9.534)$ & & \\
\hline \multirow[t]{2}{*}{ LOTRI $*$ small } & & & -0.113 & \\
\hline & & & $(0.108)$ & \\
\hline \multirow[t]{2}{*}{ LOTRI $*$ large } & & & -0.802 & \\
\hline & & & $(0.655)$ & \\
\hline \multirow[t]{2}{*}{ LMAOTRI $*$ small } & & & & $1.285^{* *}$ \\
\hline & & & & $(0.682)$ \\
\hline \multirow[t]{2}{*}{ LMAOTRI $*$ large } & & & & 1.164 \\
\hline & & & & $(0.860)$ \\
\hline Observations & 18905 & 18905 & 18905 & 18905 \\
\hline Pseudo $R$-squared & 0.08 & 0.08 & 0.08 & 0.08 \\
\hline
\end{tabular}

${ }^{*}$ Significant at $10 \% ;{ }^{* *}$ significant at $5 \% ;{ }^{* * *}$ significant at $1 \%$. Source: see Table 2.

All models include the same set of control variables not included in Table 3 (female, age, age ${ }^{2}$, upper class, lincome, attend religion, chauvinism, pride).

exports in international markets, the higher the support for protectionism. Then, exports are viewed as a counterweight to the removal of national restrictions.

The theory of protection shows that trade policy instruments do not have the same impact on a small or large country. In fact, a large demand or supply of a large country enables the country to influence international prices and could make duties on imports or subsidies for exports more optimal in this case. According to this economic logic, people living in big countries should be more protectionist. To check if people are aware of this argument, we interact the trade policy indicators with a dummy indicating the size of the country. We find that a high level of protection does not have an influence on individual support for protectionism in small or large countries. When we split the MAOTRI index into two variables according to the size of the countries, we observe that the access granted to exports increases protectionism support in small countries. People value the facilities given or restrictions imposed by their trading partners when making decisions concerning their own trade policy and this is especially true for small countries.

\section{Conclusions}

In this study, we hypothesise that individual support for protectionism is not only affected by noneconomic factors, such as the respondent's attachment or nationalism values or personal economic situations, but also by some macroeconomic factors. To test our proposal, we explain protectionism support using an ordered probit model that includes individual attributes and country characteristics. We use data on individual preferences for free trade from the ISSP survey. Unfortunately, the version of ISSP that includes the preference concerning free trade is only available for the year 2003. Although these data are somewhat dated, they are the most recent to test our hypotheses. The dataset is available for more than thirty countries and offers a very interesting database for our purpose. We complete this rich database with a wide range of macroeconomic indicators collected from different databases. In particular, we use indicators concerning macroeconomic context (GNI per capita, inflation, unemployment rates, and risk index), importance of trade and size of the country, and, more originally, indicators concerning the restrictiveness of trade policies for imports and exports.

Some of our conclusions are similar to those of Daniels and von der Rhur [20] and Mayda and Rodrik [5], among others; namely, social status, relative income, values, and attachments have a notable influence on the formation of preferences. Like these studies, we also provide evidence that protrade preferences are positively and robustly correlated with individuals' level of human capital. We also confirm that individual opinions concerning free trade match with how their personal revenue could be affected in the medium or 
long term by trade liberalisation as predicted by comparative advantage models. In fact, our results are in line with the R-V model: working in a sector with a comparative disadvantage also increases protectionism support, whereas working in a sector with a comparative advantage does not influence respondents' opinions. Hence, people's opinions are in line with the direct consequences trade liberalisation would have on its revenue.

Our main contribution consists in testing the influence of some macroeconomic factors on individual preferences for free trade. We find evidence that their overall appreciation of the consequence of trade liberalisation for the whole economy is not in line with trade theory optimism for free trade. A large increase in the unemployment rate or inflation rate increases protectionist attitudes, indicating that individuals do not trust that free trade will lead to lower prices or create jobs. In an unstable macroeconomic context, the fear of adjustment costs outweighs the positive effect that free trade could bring through a reallocation of resources.

We test if protectionism support is influenced by the dependence of the individuals' country of residence on external trade as reflected in the import penetration rate and export ratio. We find a positive relation between the import penetration rate and protectionism support, especially in small countries. In other words, foreign products are seen as a threat for national production rather than an opportunity for consumers. Our results suggest that people reject the possibility that trade liberalisation could alleviate the balance of payments problem in dependent countries by lowering prices. In the same line, people positively value exports, especially in small countries. Hence, our results offer clear proof that the public does not embrace free trade and Smith's laissez-faire, at least through a more neomercantilism view which considers that a favourable balance of trade is associated with a healthy economy; a situation that should be reached according to this view through protectionism measures.

We also confirm that trade restriction levels applied by countries are positively correlated with average support for protectionism among residents. One explanation for this is that trade policies respond to public demands. We also test if trade policies in turn influence public demand for trade policies. Although high protection on imports could increase the inconvenience of protectionism, the positive impact of projectionist measures (after controlling for endogeneity bias) is undetermined. We find that protectionist measures imposed by the respondent's country do not significantly influence protectionism support in general. It remains unclear that our result is due to reverse causality or the fact that people are not aware of the real level of protectionism or are really not sensitive to this aspect. We have also tested how easy access to their exports reduces people's support for restrictive measures on imports. We find that poorer access to international markets has a significant and positive impact on support for import protectionism. This demonstrates that exports are viewed as a counterweight to the removal of national restrictions.

Since individuals' opinions towards trade policies do not only depend on noneconomic factors such as values and demographic characteristics but also on the labour market situation and macroeconomic contexts, recessions may increase protectionism pressures. Our study also shows that people are sensitive to the access granted by their trade partners to national exports and that pressures could therefore spread quickly from one country to another. It appears that the best way to overcome the pessimistic view about free trade is to increase skills. Indeed, more educated people are more likely to favour free trade wherever they live. Providing transparent information about trade restrictions, trade composition and the importance of export sectors and foreign markets might also reduce support for protectionism.

\section{Acknowledgments}

J. Milgram-Baleix gratefully acknowledges the financial support from SEJ 340 of the Junta de Andalucía and the MICINN project ECO2011-25737.

\section{References}

[1] K. Gawande and P. Krishna, "Political Economy of U.S. Trade Policy: empirical approaches," in Handbook of International Economics, J. Harrigan and E. Kwan Choi, Eds., pp. 213-250, Blackwell, Oxford, UK, 2003.

[2] K. H. O'Rourke and R. Sinnott, "The determinants of individual attitudes towards immigration," European Journal of Political Economy, vol. 22, no. 4, pp. 838-861, 2006.

[3] A. Baker, "Who wants to globalize? Consumer tastes and labor markets in a theory of trade policy beliefs," American Journal of Political Science, vol. 49, no. 4, pp. 924-938, 2005.

[4] E. Beaulieu, V. Dehejia, and H. O. Zakhilwal, "International trade, labour turnover, and the wage premium: testing the Bhagwati-Dehejia hypothesis for Canada," CESifo Working Paper Series 1149, 2004.

[5] A. M. Mayda and D. Rodrik, "Why are some people (and countries) more protectionist than others?" European Economic Review, vol. 49, no. 6, pp. 1393-1430, 2005.

[6] E. Beaulieu, R. A. Yatawara, and W. G. Wang, "Who supports free trade in Latin America?" World Economy, vol. 28, no. 7, pp. 941-958, 2005.

[7] I. Sanz and F. Martínez-I-Coma, "Skill and support to globalization in the EU," Applied Economic Letters, vol. 15, pp. 271-275, 2008.

[8] D. Denslow and T. M. Fullerton, "Consumer attitudes toward trade liberalization," Applied Economics Letters, vol. 3, no. 3, pp. 179-182, 1996.

[9] K. Scheve and M. J. Slaughter, "Economic insecurity and the globalization of production," American Journal of Political Science, vol. 48, no. 4, pp. 662-674, 2004.

[10] A. Caplanova, M. Orviska, and J. Hudson, "Eastern European attitudes to integration with western Europe," Journal of Common Market Studies, vol. 42, no. 2, pp. 271-288, 2004.

[11] M. Gabel, Interests and Integration: Market Liberalization, Public Opinion, and the European Union, University of Michigan Press, Ann Arbor, Mich, USA, 1998.

[12] D. Rodrik, Has Globalization Gone Too Far? Institute for International Economics, Washington, DC, USA, 1998.

[13] O. Doyle and J. Fidrmuc, "Who favors enlargement?: determinants of support for EU membership in the candidate countries 
referenda," European Journal of Political Economy, vol. 22, pp. 520-543, 2006.

[14] L. Guiso, P. Sapienza, and L. Zingales, "People's opium? Religion and economic attitudes," Journal of Monetary Economics, vol. 50, no. 1, pp. 225-282, 2003.

[15] CEPII, "CHELEM database," Centre d'Etudes Prospectives et d'Informations Internationales, Paris, France, 2006, http://www .cepii.fr/anglaisgraph/bdd/chelem.htm.

[16] World Bank, "World Development Indicators 2004," 2008, http://publications.worldbank.org/WDI/.

[17] J. E. Anderson and J. P. Neary, "A new approach to evaluating trade policy," Policy Research WP-1022, World Bank, 2001.

[18] E. Helpman and P. Krugman, Market Structure and Foreign Trade, MIT Press, Cambridge, UK, 1996.

[19] C. Ai and E. C. Norton, "Interaction terms in logit and probit models," Economics Letters, vol. 80, no. 1, pp. 123-129, 2003.

[20] J. P. Daniels and M. von der Ruhr, "God and the global economy: religion and attitudes towards trade and immigration in the United States," Socio-Economic Review, vol. 3, no. 3, pp. 467-489, 2005. 


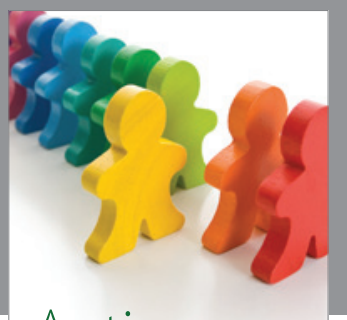

Autism

Research and Treatment
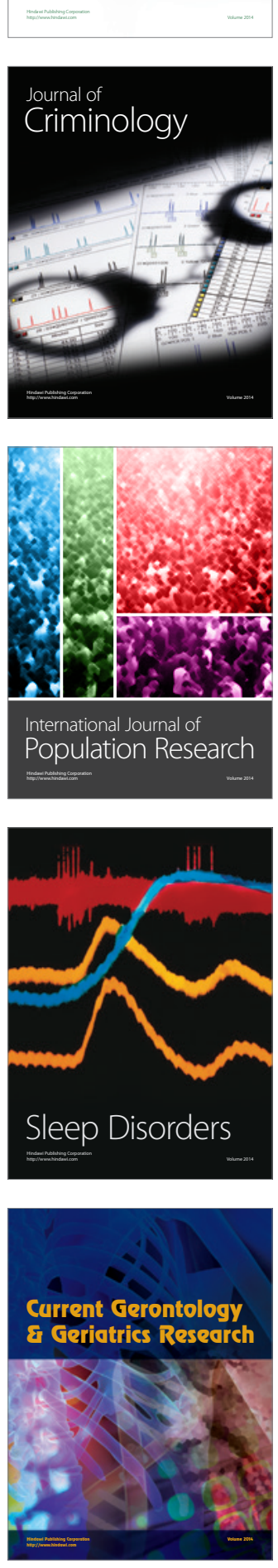
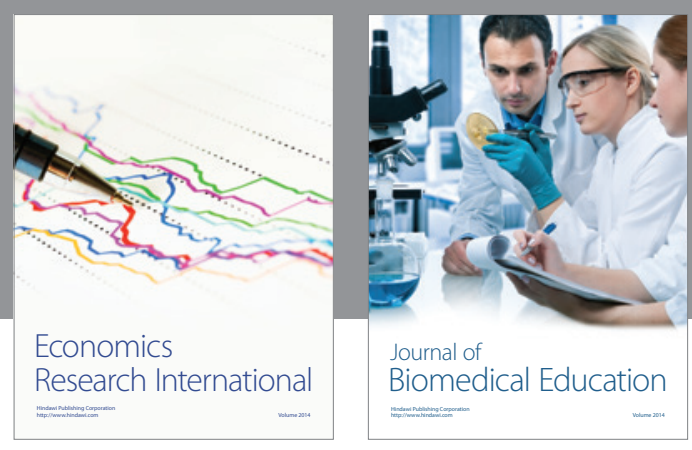

Journal of

Biomedical Education

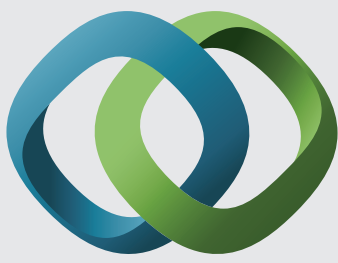

\section{Hindawi}

Submit your manuscripts at

http://www.hindawi.com
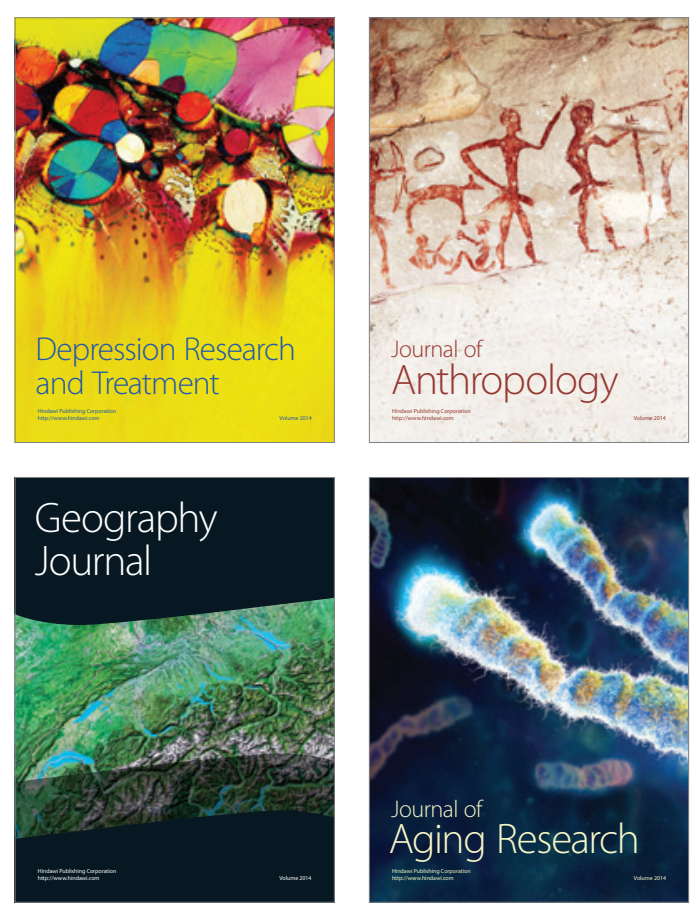

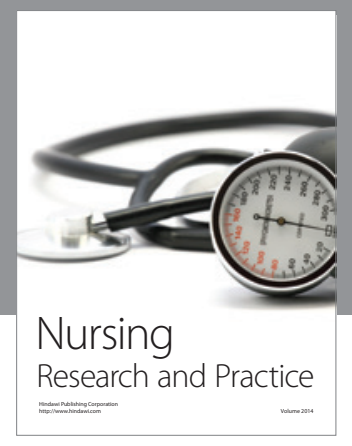

Nursing

Research and Practice

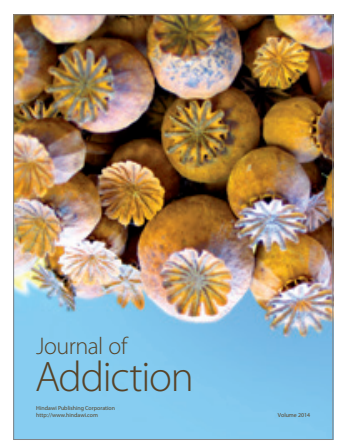

Child Development

Research

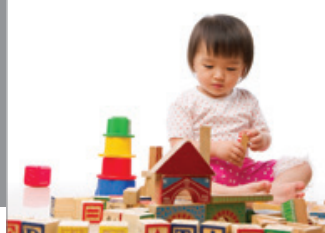

迥
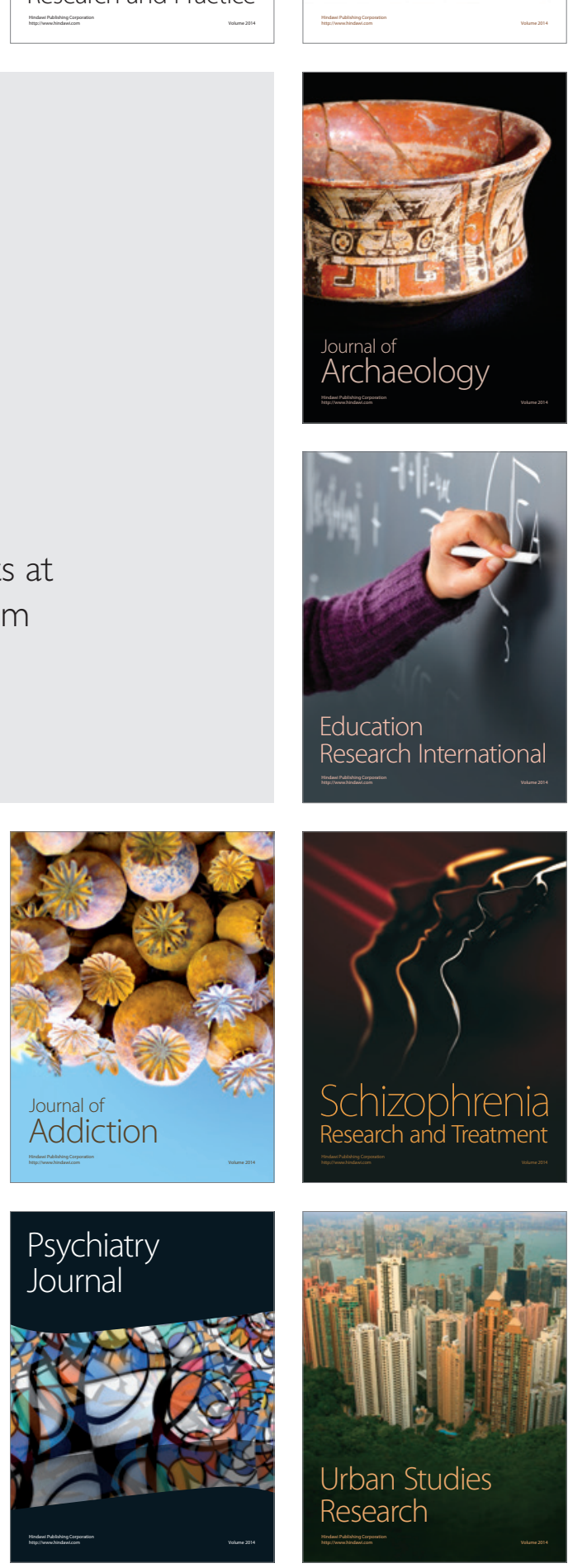